\title{
VARIOUS APPROACHES TO ENHANCE THE DISSOLUTION OF LORNOXICAM FAST DISSOLVING TABLETS PREPARED BY USING DIFFERENT CATEGORIES OF SUPERDISINTEGRANTS: A COMPARATIVE STUDY
}

\author{
Acharya $\mathrm{A}^{1^{*}}$, Kumar GB K ${ }^{1}$, Goudanavar $\mathrm{P}^{1}$, Dhakal $\mathrm{K}^{2}$, \\ ${ }^{1}$ Department of Pharmaceutics, Sri Adichunchanagiri College of Pharmacy, B.G.Nagara-571 \\ 448, Mandya Dist. Karnataka, India. \\ ${ }^{2}$ Department of Pharmacology, Asian College for Advance Studies, Kathmandu, Nepal. \\ *Corresponding author:
}

Ankit Acharya, PhD Research Scholar, Department of Pharmaceutics, Sri Adichunchanagiri College of Pharmacy,B.G. Nagara-571 448,Mandya Dist.Karnataka, India. Email ID: ankitbaba99@gmail.com

\section{ABSTRACT}

Background: Recent developments in fast dissolving tablets have brought convenience in dosing to pediatric and elderly patients who have trouble in swallowing tablets. The main objective of the present study is to formulate fast dissolving tablet of Lornoxicam by direct compression method.

Methods: Guar gum and crospovidone were used as natural and synthetic superdisintegrants respectively. Fast dissolving tablet of Lornoxicam were prepared by direct compression technique using three different approaches; superdisintegrant addition, sublimation, and solid dispersion.

Results: IR and DSC studies showed no interaction between the drug and the excipients. All formulation showed disintegration time ranging from 16.09-42.54 second. Wetting time and disintegration time decreased by increasing the super disintegrant concentration from $2.5 \%$ to $5 \% \mathrm{w} / \mathrm{w}$. Formulae L16 gave the best in-vitro disintegration and dissolution results, which would be due to swelling effect of Gaur gum and amorphization of the drug during the solid dispersion preparation. The best formulation L16 was subjected to stability testing for 3 month and results showed no significant change in appearance, hardness, drug content and dissolution profile of the tablets, hence tablet is stable throughout its stability studies.

Conclusion: It was concluded that fast dissolving tablets of Lornoxicam were formulated successfully with desired characteristics which disintegrated rapidly; provided rapid onset of action; and enhanced the patient convenience and compliance.

Keywords: Disintegration time, Fast dissolving tablet, Lornoxicam, PEG 6000, Sublimation, Solid dispersion.

\section{INTRODUCTION}

Drug delivery system is an efficient tool for extending the product life cycles, creating wonderful opportunities to the pharmacist and also it makes a significant contribution to global pharmaceutical sales through market segmentation ${ }^{1}$. 
Despite of tremendous innovations in drug delivery, oral route of drug administration have wide acceptance up to $50-60 \%$ of total available dosage forms ${ }^{2}$. Among all dosage forms solid oral dosage forms (tablets and capsules) are more popular because of ease of administration, accuracy in dose, self-medication, pain less, and most important is good patient compliance ${ }^{3}$. Problem related to dysphagia i.e. difficulty in swallowing, is common among all age groups. According to a survey, dysphagia is common in about $35 \%$ of the general population as well as an additional 30-40\% of elderly institutionalized patients. Geriatric, paediatric and traveling patients who may not have ready access to water are most in need of easy swallowing dosage forms ${ }^{3}$. In order to avoid above problem approaches have been taken for the development of a new dosage form that can improve patient compliance ${ }^{4}$.Solid oral dosage forms that can be dissolved or suspended with water in the mouth for easy swallowing are highly desirable for the paediatric and geriatric population, as well as traveling patients who prefer the convenience of readily administered dosage forms. Fast disintegrating tablet (FDTs) technologies has been developed during last decades that make tablets which disintegrate in the mouth without chewing and additional water intake and/or with a very small amount (e.g., 1-2 mL) of water but disintegration fluid is provided by the saliva of the patient ${ }^{5}$.FDTs have all the advantages of solid dosage forms such as good stability, accurate dosing, easy manufacturing, small packaging size, and easy handling by patients ${ }^{6}$.Fast dissolving tablet is also known as fast melting, fast dispersing, rapid dissolve, rapid melts, fast dissolving tablets and/or quick disintegrating tablet. Fast dissolving tablet is approved by various regulatory agencies like Food and Drug Administration (FDA) and European Pharmacopeia, where FDA defines FDTs as "A solid dosage form containing medicinal substances which disintegrates rapidly, usually within a matter of seconds, when placed upon the tongue", The disintegration time for good FDTs varies from few seconds to about a minute. Decrease in disintegration time assists easy swallowing and also plays a role in drug absorption in buccal cavity, thus increases bioavailability by bypassing hepatic metabolism of drugs and moreover, the amount of drug is reduced as compared to conventional tablets ${ }^{3,7}$.

Sugar-based excipients i.e. Mannitol shows a negative heat of dissolution, dissolve quickly in saliva, and provide a pleasing mouth feel and sweetness to the final product ${ }^{7}$.To improve porosity of prepared tablets, volatile substances such camphor can be used in tabletting process which gets sublimated from the formed tablets ${ }^{8,9}$.

An attempt has been made to formulate fast dissolving tablet of Lornoxicam using synthetic and natural super disintegrants. Gaur gum was used as natural super disintegrant as it is nontoxic, non-irritating, abundantly available and cheaper. Since Gaur gum gives promising results on disintegration time and dissolution rate, it is helpful for Pharma industry as well as patients from economic point view ${ }^{10,11}$. In this present study Lornoxicam was selected for the formulation of fast dissolving tablet. Two combined approaches; solid dispersion and sublimation technique along with superdisintegrant addition was used to prepare FDTs, which shall not only increases solubility and bioavailability but also improve patient compliances and patient convenience ${ }^{3,4,11}$.

Lornoxicam is one of the oxicam derivative belongs to non-steroidal anti-inflammatory drugs (NSAIDs) which possess analgesic, anti-inflammatory and anti-pyretic properties. It is also prescribed for osteoarthritis, rheumatoid arthritis, acute lumbar-sciatica conditions and for post-operative pain management. It has half-life of 3 to $5 \mathrm{hrs}$ and peak plasma concentration is attained within $2.5 \mathrm{hrs}$. Lornoxicam is ten times more potent than other oxicam derivatives. Its daily dose is $8-16 \mathrm{mg}$ taken before meal but dose above $8 \mathrm{mg}$ should be divided into two 
or more doses.Like all NSAIDs it acts by inhibiting the metabolites of COX branch of arachidonic acid pathway. It inhibits both isoforms in the same concentration range i.e. COX$1 / \mathrm{COX}-2=1$. Thus, a perfectly balanced inhibition of COX-1 and COX-2 is achieved.Lornoxicam is slightly soluble in simulated gastric fluid ${ }^{12,13,14,15}$.

In the present study Lornoxicam fast dissolving tablet was prepared by direct compression technique using three different approaches namely; superdisintegrant addition, sublimation and solid dispersion using novel superdisintegrants in order to improve its dissolution rate and hence its bioavailabity.

\section{MATERIALS AND METHODS}

\section{Drugs and chemicals}

Lornoxicam was obtained as gift sample from Naprod Life Sciences P.LTD (India), Crospovidone, Gaur gum, PEG 6000 were procured from S.D fine chem limited, Mumbai (India), Camphor, Magnesium stearate, Aspartame and Mannitol were analytical grade.

\section{Methods}

\section{Differential scanning calorimetric studies (DSC)}

Thermal properties of the pure Lornoxicam and the physical mixture of drug and excipients were analysed by Shimadzu DSC-60, Shimadzu Limited Japan. The samples were heated in a thermetically sealed aluminium pans. Heat runs for each sample were set from 25 to $350^{\circ} \mathrm{C}$ at a heating rate of $10^{\circ} \mathrm{C} / \mathrm{min}$ using nitrogen as blanket gas to eliminate the oxidative and pyrolytic effects. Samples of weight $3-5 \mathrm{mg}$ were used for the analysis and finally the DSC thermograms were recorded.

\section{Fourier transform infrared spectroscopy (FTIR)}

IR spectra of the pure drug and the physical mixture of drug and excipients were conducted using a Thermo Nicolet FTIR and the spectrum was recorded in the region of 4000 to 400 $\mathrm{cm}^{-1}$. All spectra were collected as an average of three scans at a resolution of $2 \mathrm{~cm}^{-1}$.

\section{Preparation of Lornoxicam fast dissolving tabletby superdisintegrant addition method}

FDTs of Lornoxicam were prepared by direct compression technique using three different approaches; superdisintegrant addition, sublimation and solid dispersion ${ }^{4}$. Table 1 shows the composition of Lornoxicam FDTs, each containing $8 \mathrm{mg}$ of pure drug. In all formulations Mannitol was used as diluent. Aspartame was used as sweetening agent. The calculated quantity of drug and excipients were weighed accurately and passed through sieve 100 \# separately. Sieved powder materials were transferred to mortar in geometrical dilution method and mixed well for about $10 \mathrm{~min}$ and at the end of mixing lubricants were added (Talc, Mg stearate) and further mixed for $5 \mathrm{~min}$. Finally physical mixtures were compressed into tablets using single punch tablet machine (Lab Press, India) using $8 \mathrm{~mm}$ flat surface punches under $2-4 \mathrm{~kg} / \mathrm{cm}^{3}$ compression force.

\section{Preparation of Lornoxicam fast dissolving tablets by sublimation method}

The steps involved in the preparation of FDTs by sublimation technique were same as superdisintegrant addition technique except that this technique possesses sublimating agents like Camphor. After compression tablets were heated in a hot air oven at $60^{\circ} \mathrm{C}$ until constant weight was obtained which indicated complete removal of volatilizable component ${ }^{16}$. Formulations bearing code L5 to L12 were prepared by sublimation technique (table 2). 
Original Article

Table 1:Composition of Lornoxicam fast dissolving tablets prepared by superdisintegrant addition method

\begin{tabular}{lcccc}
\hline Ingredients (mg) & \multicolumn{3}{c}{ Formulation code } \\
\cline { 2 - 5 } & L1 & L2 & L3 & L4 \\
\hline Lornoxicam & 8 & 8 & 8 & 8 \\
Crospovidone & 2.5 & 5 & - & - \\
Gaur gum & - & - & 2.5 & 5 \\
Aspartame & 1.5 & 1.5 & 1.5 & 1.5 \\
Menthol & 1 & 1 & 1 & 1 \\
Magnesium stearate & 2 & 2 & 2 & 2 \\
Talc & 1 & 1 & 1 & 1 \\
Mannitol up to & 100 & 100 & 100 & 100 \\
\hline
\end{tabular}

Table 2: Composition of Lornoxicam fast dissolving tablets prepared by sublimation method.

\begin{tabular}{lcccccccc}
\hline Ingredients (mg) & \multicolumn{7}{c}{ Formulation code } \\
\cline { 2 - 8 } & L5 & L6 & L7 & L8 & L9 & L10 & L11 & L12 \\
& 8 & 8 & 8 & 8 & 8 & 8 & 8 & 8 \\
Lornoxicam & 5 & 5 & 10 & 10 & 5 & 5 & 10 & 10 \\
Camphor & 2.5 & 5 & 2.5 & 5 & - & - & - & - \\
Crospovidone & - & - & - & - & 2.5 & 5 & 2.5 & 5 \\
Gaur gum & 1.5 & 1.5 & 1.5 & 1.5 & 1.5 & 1.5 & 1.5 & 1.5 \\
$\begin{array}{l}\text { Aspartame } \\
\text { Menthol }\end{array}$ & 1 & 1 & 1 & 1 & 1 & 1 & 1 & 1 \\
$\begin{array}{l}\text { Magnesium } \\
\text { stearate }\end{array}$ & 2 & 2 & 2 & 2 & 2 & 2 & 2 & 2 \\
\begin{tabular}{l} 
Talc \\
\hline
\end{tabular} & 1 & 1 & 1 & 1 & 1 & 1 & 1 & 1 \\
\hline
\end{tabular}




\begin{tabular}{lllllllll}
\hline Mannitol up to & 100 & 100 & 100 & 100 & 100 & 100 & 100 & 100
\end{tabular}

\section{Preparation of Lornoxicam fast disintegrating tablets by solid dispersion method}

Lornoxicam solid dispersions were prepared by solvent evaporation method using PEG 6000 as polymeric carrier in drug to carrier ratios of 1:4. Drug was weighed accurately and transferred into a china dish, drug was dissolved in methanol and then polymeric carrier was added. The china dish was kept in water bath at $45^{\circ} \mathrm{C}$ and mixture was triturated until complete evaporation of added solvent. Finally dried mass formed on china dish was scrapped, crushed with spatula and then passed through sieve \# 100. The powdered solid products were kept in a desiccator to dry for $24 \mathrm{hrs}$ over anhydrous calcium chloride ${ }^{11}$. An amount equivalent to $8 \mathrm{mg}$ of drug was formulated as fast dissolving tablets where, formulation L13-L14 and L15-L16 contains Crospovidone and Gaur gum superdisintegrants, respectively.

\section{Determination of solubility of solid dispersion}

Solid dispersion equivalent to $8 \mathrm{mg}$ of Lornoxicam was added to $10 \mathrm{ml}$ each of distilled water and phosphate buffer ( $\mathrm{pH}$ 6.8). The dispersions were shaken well and kept aside for $24 \mathrm{hrs}$. The solution was filtered and analysed spectrophotometrically at $371 \mathrm{~nm}$ (UV-1800 spectrophotometer, shimadzu, Japan) after appropriate dilutions ${ }^{11}$.

\section{Solubility studies}

According to results obtained from solubility studies, there were significant changes in solubility of drug and physical mixtures compared to that of pure drug in distilled water as well as phosphate buffer ( $\mathrm{pH}$ 6.8). Solubility of physical mixtures in distilled water and phosphate buffer $(\mathrm{pH}$ 6.8) found to be increased with increase in carrier ratio up to 1:4. Solubility was slightly decreased at drug to carrier ratio of 1:5. The obtained results showed that with increase in concentration of carriers, solubility of Lornoxicam increases up to certain level (1:4), further increase in concentration slightly lowers its solubility. Enhanced solubility of Lornoxicam from the physical mixtures could be related to surface activity which may reduce agglomeration and hence increased surface area, and solubilizing effect of PEG 6000. Hence, based on solubility results solid dispersion containing drug to carrier ratios of 1:4 was selected for preparation of tablets.

Table 3: Solid dispersion of Lornoxicam in different drug and carrier ratios.

\begin{tabular}{cccc}
\hline $\begin{array}{c}\text { Ratio } \\
\text { Lornoxicam:PEG6000 }\end{array}$ & $\begin{array}{c}\text { Physical } \\
\text { mixtures } \\
\text { code }\end{array}$ & $\begin{array}{c}\text { Solubility in water } \\
(\mathbf{m g} / \mathbf{m l})\end{array}$ & $\begin{array}{c}\text { Solubility in 6.8 } \mathbf{~ p H} \\
\text { Phosphate buffer } \\
(\mathbf{m g} / \mathbf{m l})\end{array}$ \\
\hline Lornoxicam pure drug & AA-1 & 0.038 & 0.143 \\
$\mathbf{1 : 1}$ & AA-2 & 0.052 & 0.171 \\
$\mathbf{1 : 2}$ & AA-3 & 0.068 & 0.194 \\
$\mathbf{1 : 3}$ & AA-4 & 0.073 & 0.199 \\
\hline
\end{tabular}


Original Article

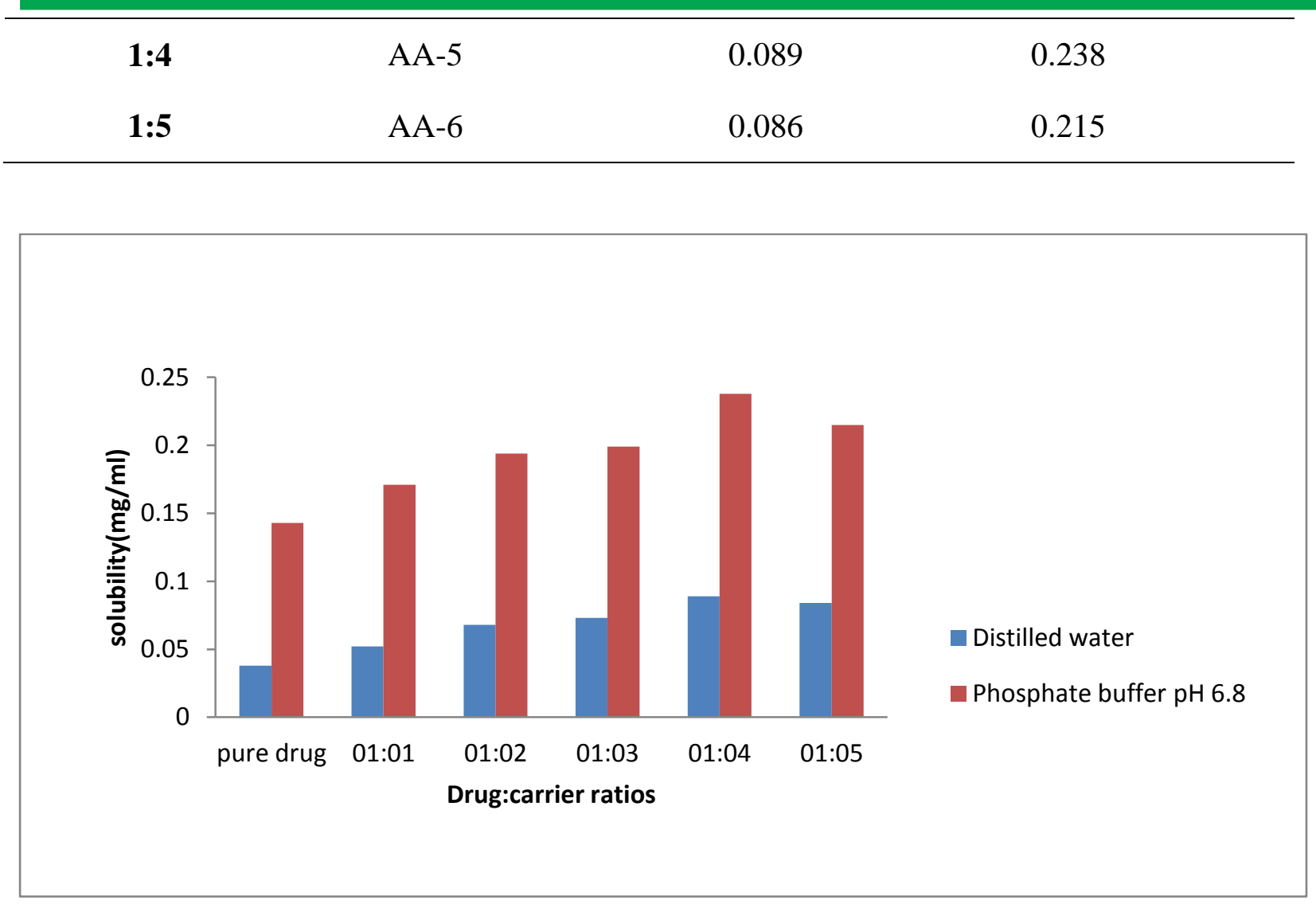

Fig 1: Solubility profile of Lornoxicam in solid dispersion prepared by different drug and carrier ratios.

Table 4: Composition of Lornoxicam fast dissolving tablets prepared by solid dispersion method.

\begin{tabular}{lcccc}
\hline \multicolumn{1}{c}{ Ingredients(mg) } & \multicolumn{4}{c}{ Formulation code } \\
\cline { 2 - 5 } & L13 & L14 & L15 & L16 \\
\cline { 2 - 5 } AA-5 (SD) \# 8 & 40 & 40 & 40 & 40 \\
Crospovidone & 2.5 & 5 & - & - \\
Gaur gum & - & - & 2.5 & 5 \\
Aspartame & 1.5 & 1.5 & 1.5 & 1.5 \\
Menthol & 1 & 1 & 1 & 1 \\
Magnesium stearate & 2 & 2 & 2 & 2 \\
Talc & 1 & 1 & 1 & 1 \\
\hline
\end{tabular}




\begin{tabular}{lllll}
\hline Mannitol up to & 100 & 100 & 100 & 100 \\
\hline
\end{tabular}

\section{Pre-compression evaluations}

Before compression, powder mixtures were evaluated for their pre-compression parameters such as angle of repose $(\Theta)$, bulk density $\left(D_{v}\right)$, true density $\left(D_{t}\right)$, compressibility index $(C I)$, Hausner ratio $(\mathrm{H})$. From these parameters flow properties and compressibility properties of powder mixtures were determined ${ }^{1,17,18}$.

\section{Post compression parameters of prepared tablets}

After compression, prepared tablets were evaluated for various parameters such weight variation, hardness, friability, wetting time, water absorption ratio, drug content, disintegrating time $\mathrm{i}^{10,16,17,18,19,20}$.

\section{In- vitro dissolution studies}

In- vitro dissolution studies were carried out using USP type II paddle type dissolution apparatus (Lab India). The dissolution medium used was $\mathrm{pH} 6.8$ phosphate buffer $(900 \mathrm{ml})$ maintained $37 \pm 5^{\circ} \mathrm{C}$ with a paddle rotation speed at $50 \mathrm{rpm}$. $10 \mathrm{ml}$ sample was withdrawn at predetermined time interval 1, 5, 10, 15, $30 \mathrm{~min}$ and replaced with same volume of fresh dissolution medium. Absorbance of this solution was measured at $371 \mathrm{~nm}$. Drug concentration was calculated and expressed as cumulative percentage of the drug released. The dissolution tests were carried out three times ${ }^{20}$.

\section{Kinetic data analysis}

The in-vitro release data were analysed by various kinetic model, such as Zero order kinetic model, First order kinetic model, Higuchi model, and Korsmeyer/Peppas model ${ }^{21}$.

\section{Stability testing}

Short-term stability studies of an optimized formulation were carried out at $25^{\circ} \mathrm{C} / 60 \% \mathrm{RH}$ and $40^{\circ} \mathrm{C} / 75 \%$ for 3 months (as per ICH guidelines) in stability chamber (LAB TOP, Mumbai). First tablets were sealed in aluminium packing and then packed in the amber coloured rubber stoppered vial. Tablets were withdrawn periodically at 1,2 and 3 month respectively and evaluated for hardness, friability, drug content, and in-vitro dissolution studies as per ICH-Guidelines ${ }^{20}$.

\section{RESULTS AND DISCUSSION}

Three different approaches i.e. superdisintegrant addition, sublimation, solid dispersion methods were used. In this present work, two different categories of super disintegrants were used; Crospovidone as synthetic superdisintegrant and Gaur gum as natural superdisintegrant in two different concentrations like $2.5 \%$ and $5 \%$. Mannitol was used to impart multifunctional benefits like good aqueous solubility and good wetting properties which facilitated tablet breakdown as well as negative heats of solution giving cooling effect in the mouth. PEG 6000 was used as carrier for preparation of solid dispersion with Lornoxicam due to its solubility in water, physiologically inert, thermally stable at melting temperature, lack of absorption, and improved compound wettability.

\section{Compatibility study}




\section{Fourier transform infrared spectroscopy (FTIR)}

Compatibility between the pure drug (Lornoxicam) and its physical mixtures with various excipients used in preparation of fast dissolving tablet formulations were characterized by FT-IR spectroscopy to test. FT-IR spectra of Lornoxicam and its physical mixture with excipients showed the same characteristic bands of the drug in the same region and same ranges, indicating no interaction between the drugs and excipients. Lornoxicam showed significant bands at $3065.53 \mathrm{~cm}^{-1}$ for $\mathrm{NH}$ stretch, $1594.04 \mathrm{~cm}^{-1}$ for $\mathrm{C}=\mathrm{O}$ and $1083.51 \mathrm{~cm}^{-1}$ for $\mathrm{S}=\mathrm{O}$ stretch and $788.41 \mathrm{~cm}^{-1}$ for $-\mathrm{Cl}$ stretch. This indicated further identity and purity of LXM. The chemical integrity of the drug was not changed when drug was mixed with the physical mixture, indicating drug was compatible with the excipients used.

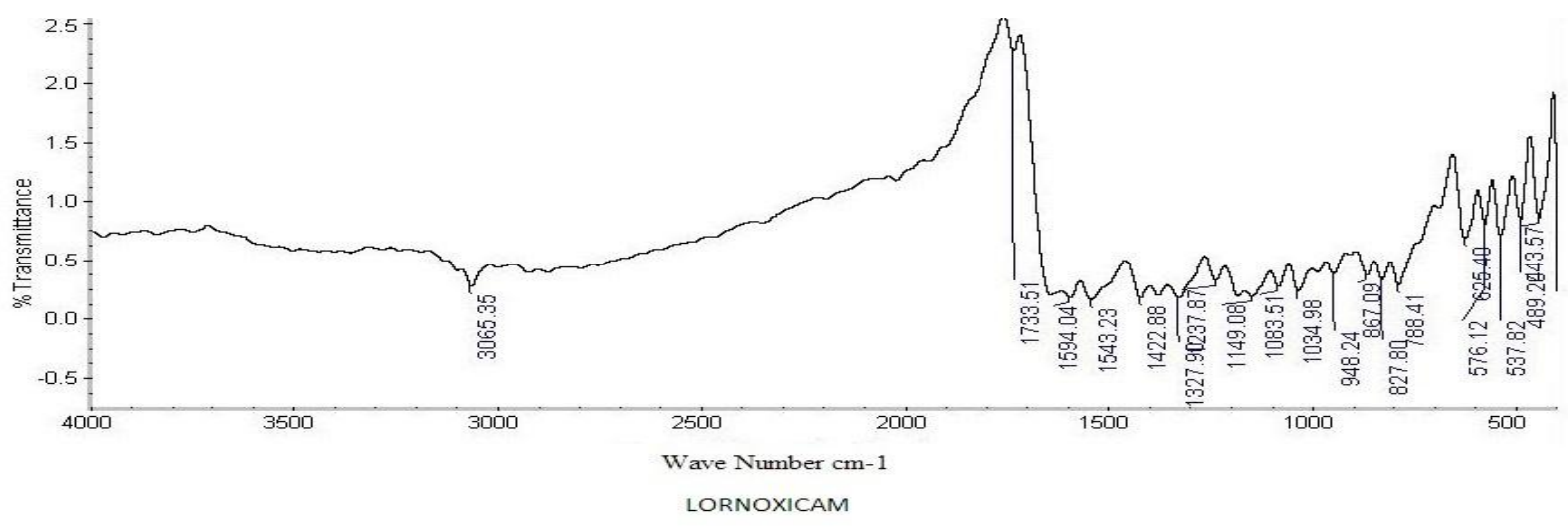

Fig 2: FT-IR Spectrum of Lornoxicam

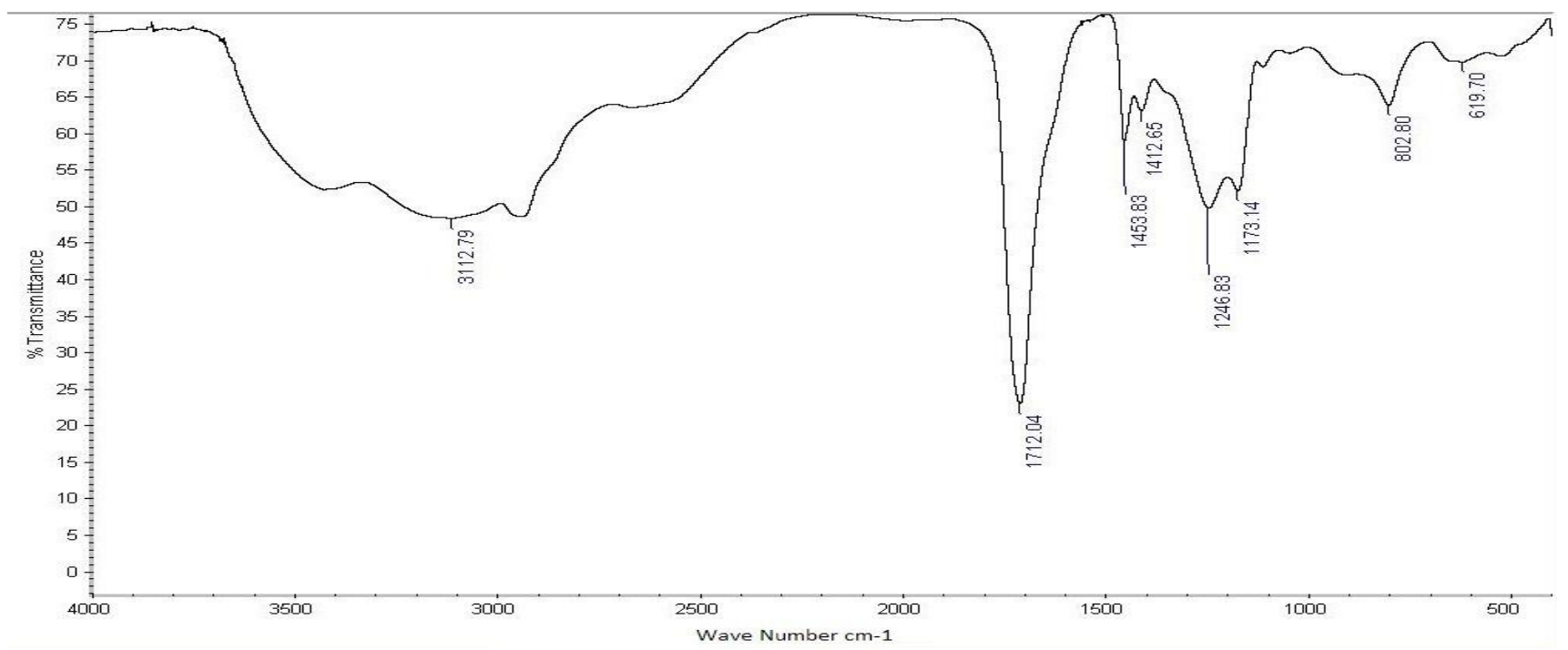

Fig 3: IR Spectrum of Lornoxicam + excipients

\section{Differential scanning calorimetric (DSC) studies}

The DSC thermogram of Lornoxicam was typical, exhibiting a sharp exothermic peak at $239.07^{\circ} \mathrm{C}$ corresponding to its melting and decomposition. These findings were similar to the Mohanty $\mathrm{S}$ et al study. ${ }^{22}$ The thermogram of the physical mixtures of Lornoxicam with excipient showed the existence of the drug exothermic peak at $223.66^{\circ} \mathrm{C}$. This showed no significant change in melting point of Lornoxicam in presence of excipients, which indicates absence of interactions between Lornoxicam and other excipients. 


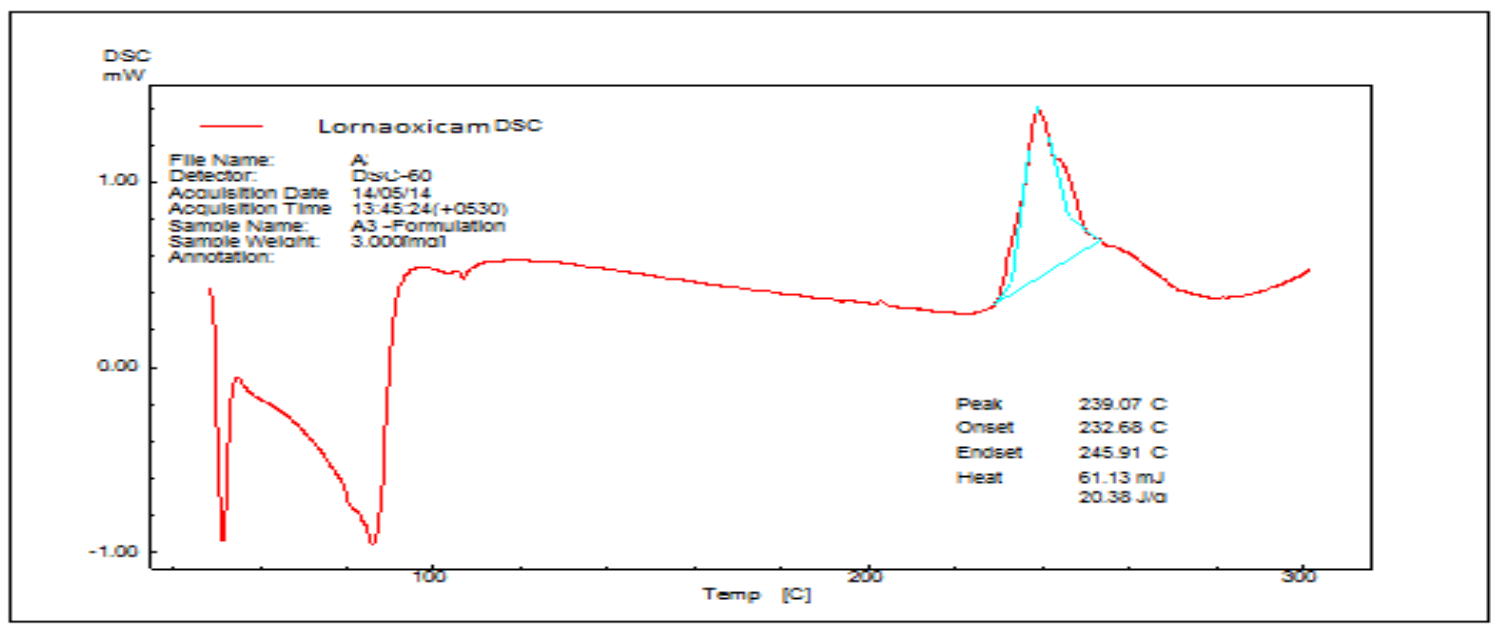

Fig 4: DSC thermogram of Lornoxicam pure drug

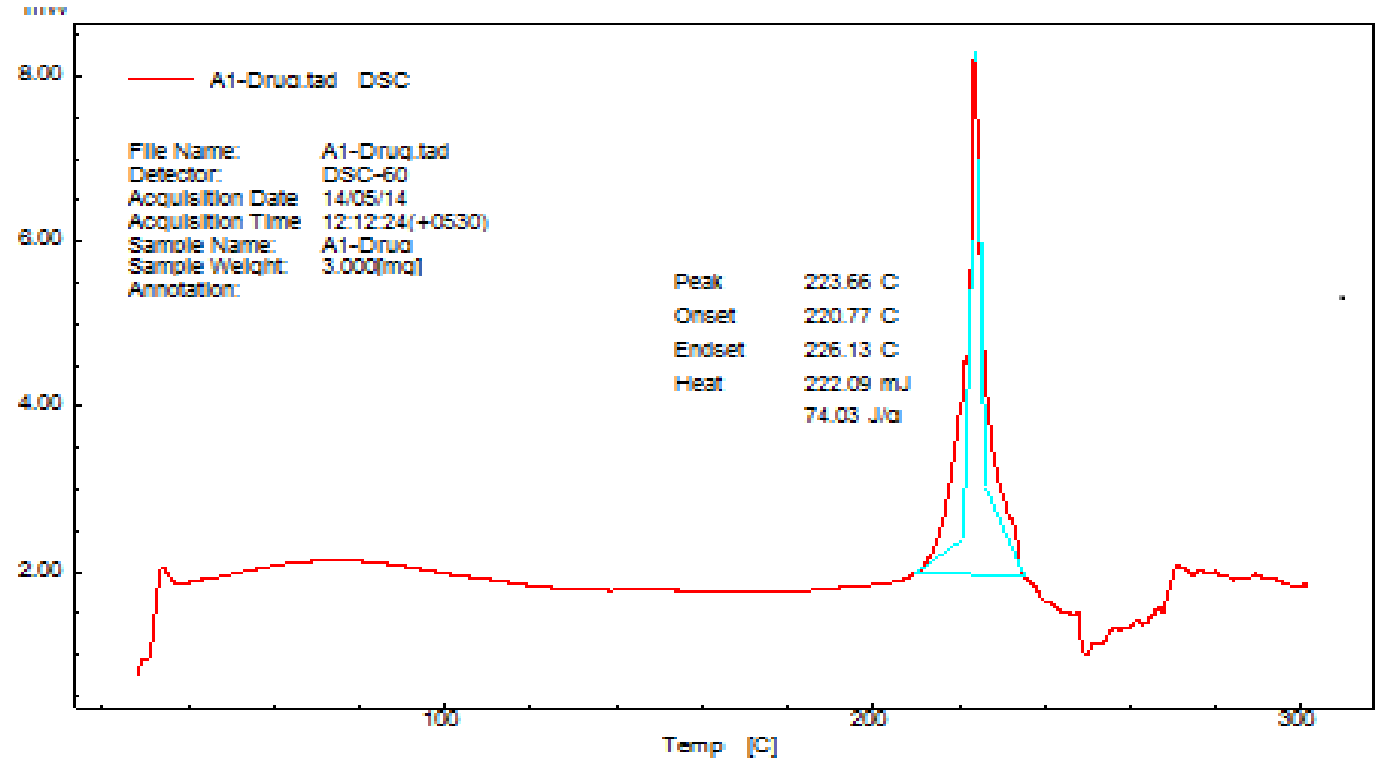

Fig 5: DSC thermogram of Lornoxicam + excipients

\section{Pre compression evaluation}

Powder is cohesive when value of angle of repose is high and non-cohesive if its value is low. The value of angle of repose $\left(21.44^{\circ}-32.33^{\circ}\right)$ represented that all formulations showed good to acceptable flow properties. Carr's index showed values up to 19.22, indicating all formulations were of acceptable to good flowability. Hausner ratio values up to 1.233 showed that powders with low inter particle friction. All formulations had Hausner ratio values within the prescribed limits and indicated a good free flowing property.

Table 5: Results of pre-compression evaluation of $\mathbf{1 6}$ different formulations

\begin{tabular}{clllll}
\hline $\begin{array}{c}\text { Formulation } \\
\text { code }\end{array}$ & $\begin{array}{l}\text { Angle of } \\
\text { repose }(\Theta)\end{array}$ & $\begin{array}{l}\text { Bulk } \\
\text { density }(\mathrm{g} / \mathrm{ml})\end{array}$ & $\begin{array}{l}\text { Tapped } \\
\text { density }(\mathrm{g} / \mathrm{ml})\end{array}$ & $\begin{array}{l}\text { Carr's } \\
\text { Index }\end{array}$ & $\begin{array}{l}\text { Haunser } \\
\text { ratio }\end{array}$ \\
\hline
\end{tabular}




\begin{tabular}{llllll}
\hline $\mathbf{L 1}$ & $32.20 \pm 0.032$ & $0.367 \pm 0.032$ & $0.439 \pm 0.042$ & $15.61 \pm 0.14$ & 1.185 \\
$\mathbf{L 2}$ & $30.56 \pm 0.022$ & $0.337 \pm 0.087$ & $0.434 \pm 0.018$ & $23.29 \pm 0.35$ & 1.203 \\
$\mathbf{L 3}$ & $32.33 \pm 0.014$ & $0.397 \pm 0.032$ & $0.440 \pm 0.0091$ & $15.48 \pm 0.21$ & 1.183 \\
$\mathbf{L 4}$ & $30.94 \pm 0.19$ & $0.367 \pm 0.061$ & $0.470 \pm 0.021$ & $17.60 \pm 0.09$ & 1.210 \\
$\mathbf{L 5}$ & $24.18 \pm 0.087$ & $0.483 \pm 0.043$ & $0.441 \pm 0.032$ & $19.11 \pm 0.14$ & 1.230 \\
$\mathbf{L 6}$ & $28.27 \pm 0.26$ & $0.338 \pm 0.073$ & $0.541 \pm 0.230$ & $18.38 \pm 0.04$ & 1.220 \\
$\mathbf{L 7}$ & $22.99 \pm 0.08$ & $0.341 \pm 0.007$ & $0.415 \pm 0.051$ & $18.02 \pm 0.08$ & 1.219 \\
$\mathbf{L 8}$ & $27.45 \pm 0.041$ & $0.420 \pm 0.028$ & $0.416 \pm 0.081$ & $16.83 \pm 0.05$ & 1.202 \\
$\mathbf{L 9}$ & $27.22 \pm 0.056$ & $0.382 \pm 0.061$ & $0.505 \pm 0.095$ & $16.21 \pm 0.23$ & 1.191 \\
$\mathbf{L 1 0}$ & $25.47 \pm 0.021$ & $0.430 \pm 0.090$ & $0.456 \pm 0.023$ & $13.81 \pm 0.76$ & 1.160 \\
$\mathbf{L 1 1}$ & $22.62 \pm 0.052$ & $0.466 \pm 0.031$ & $0.499 \pm 0.064$ & $19.22 \pm 0.09$ & 1.237 \\
$\mathbf{L 1 2}$ & $24.70 \pm 0.052$ & $0.367 \pm 0.103$ & $0.577 \pm 0.052$ & $17.98 \pm 0.41$ & 1.219 \\
$\mathbf{L 1 3}$ & $21.44 \pm 0.047$ & $0.388 \pm 0.045$ & $0.447 \pm 0.006$ & $18.91 \pm 0.05$ & 1.233 \\
$\mathbf{L 1 4}$ & $24.11 \pm 0.012$ & $0.431 \pm 0.039$ & $0.478 \pm 0.034$ & $17.51 \pm 0.12$ & 1.212 \\
$\mathbf{L 1 5}$ & $21.89 \pm 0.073$ & $0.395 \pm 0.21$ & $0.481 \pm 0.038$ & $17.77 \pm 0.16$ & 1.216 \\
\hline $\mathbf{L 1 6}$ & $27.49 \pm 0.042$ & $0.357 \pm 0.027$ & $0.405 \pm 0.012$ & $12.02 \pm 0.47$ & 1.136 \\
\hline & & & & & \\
\hline
\end{tabular}

\section{Post-compression evaluation}

As the powder mixture exhibited free flowing property, tablet produced were of uniform weight with acceptable weight variation in the range from $96.21 \mathrm{mg}$ to $101.41 \mathrm{mg}$ with the standard deviation less than $1.5 \%$ due to uniform die fill. Hardness $\left(2.60-3.43 \mathrm{~kg} / \mathrm{cm}^{2}\right)$ and friability loss (0.30-0.862 \%) indicated that tablets had a good mechanical resistance to withstand abrasion in handling, packaging and at the time of application. Drug content was found to be $95.26 \%$ to $101.54 \%$ which was within pharmacopoeial limits. Water absorption ratio and wetting time, which are important criteria for understanding dissolution profile of tablet, indicating capacity of disintegrants to swell in pressure of little amount of water. Water absorption ratio and wetting time were found to be in the range of $63.39-91.35 \%$ and 58.23-9.67 sec respectively. These results correlate with disintegration time results. The result in-vitro disintegration were within the prescribe limit and comply with the criteria for orally disintegrating tablets, the value were with $18 \pm 2.14$ to $42 \pm 3.41$. Each category of superdisintegrants (natural and synthetic) was used in two concentrations $2.5 \%$ and $5 \%$ to study their effects on disintegrating time.

Formulae L1-L4 was prepared by superdisintegrant addition method. Wetting time decrease with increase in the concentration (from $2.5 \%$ to $5 \%$ ) of both superdisintegrants. Formulation 
containing Gaur gum showed less wetting time (from 32.41 to $22.33 \mathrm{sec}$ ) compared to Crospovidone (from 42.54 to $37.29 \mathrm{sec}$ ) this may be due to increased ability of Gaur gum to absorb water and it swells which intern causes rapture of tablets.

Formulae L5-L12 was prepared by sublimation method. Camphor as subliming agent was used in two concentrations $5 \%$ and $10 \%$. The values of tablet hardness and friability were in the range of $2.75-3.44 \mathrm{~kg} / \mathrm{cm}^{2}$ and $0.33-0.92$ respectively. Present study showed addition of subliming agents had no pronounced effect on hardness and friability of prepared tablets. The concentration of subliming agents could be arranged in a descending order of decreased wetting and disintegrating time as follows: $10 \%$ camphor $>5 \%$ camphor.

Formulae L12 containing 10\% w/w camphor and 5\% Gaur gum exhibited shortest disintegration time about $18 \pm 2.14 \mathrm{sec}$ which may be due to formation of tiny pores on tablets after evaporation of volatilizable component (camphor). The porous structure is responsible for faster water uptake, so it facilities the swelling action of Gaur gum causing rupture of the tablets. The rapid disintegration of tablet assists easy swallowing and also plays important role in drug absorption in buccal cavity, thus promoting its bioavailability.

Formulae L13 to L16 were prepared by solid dispersion technique using PEG 6000 as polymeric carrier. Solubility of physical mixtures in distilled water and phosphate buffer $(\mathrm{pH}$ 6.8) found to be increased with increase in carrier ratio up to 1:4. This might be due to complete dispersion of drug with carrier (PEG 6000) at 1:4 ratio. Solubility was slightly decreased at 1:5 ratio. This might be due to formation of viscous boundary layer around the drug particle. So, solid dispersions containing the drug and carrier ratio of 1:4 was selected and tablets were formulated. The values of tablet hardness, friability and wetting time was found to be $3.33-3.78 \mathrm{~kg} / \mathrm{cm}^{2} 0.3-0.69$ and $21.23-27.45 \mathrm{sec}$ respectively.

Formulae L16 prepared by solid dispersion approach containing 5\% Gaur gum showed a decrease wetting time $(21.23 \mathrm{sec})$ compared to other formulations i.e. L13, L14, and L15. The addition of PEG 6000 as carrier promoted the wettability of the tablets thus accelerating Gaur gum swelling, leading to rapid breakdown of the tablet.

Table 6: Post compression evaluation of Lornoxicam fast dissolving tablet

\begin{tabular}{ccccccccc}
\hline $\begin{array}{c}\text { Formulation } \\
\text { code }\end{array}$ & $\begin{array}{c}\text { Weight } \\
\text { variation }\end{array}$ & $\begin{array}{c}\text { Hardness } \\
\mathbf{k g} / \mathbf{c m}^{2}\end{array}$ & $\begin{array}{c}\text { \% } \\
\text { Friability }\end{array}$ & $\begin{array}{c}\text { Wetting } \\
\text { time } \\
\text { (sec) }\end{array}$ & $\begin{array}{c}\text { Water } \\
\text { absorption } \\
\text { ratio }\end{array}$ & $\begin{array}{c}\text { Disintegration } \\
\text { time (sec) }\end{array}$ & $\begin{array}{c}\% \\
\text { drug } \\
\text { content }\end{array}$ & $\begin{array}{c}\% \\
\text { weight } \\
\text { increased } \\
\text { (after 1 } \\
\text { month) }\end{array}$ \\
\hline $\mathbf{L 1}$ & 100.51 & 3.21 & 0.67 & 58.23 & 80.21 & 42.54 & 99.78 & 0.92 \\
$\mathbf{L 2}$ & 101.41 & 2.98 & 0.69 & 47.05 & 82.56 & 37.29 & 98.58 & 1.12 \\
$\mathbf{L 3}$ & 99.87 & 3.54 & 0.53 & 42.72 & 72.45 & 32.41 & 101.6 & 1.67 \\
$\mathbf{L 4}$ & 100.23 & 3.22 & 0.43 & 41.68 & 63.39 & 22.33 & 96.56 & 1.93 \\
$\mathbf{L 5}$ & 98.64 & 2.98 & 0.72 & 32.11 & 75.12 & 30.20 & 97.99 & 1.23 \\
$\mathbf{L 6}$ & 97.09 & 3.32 & 0.63 & 29.23 & 79.88 & 27.00 & 98.78 & 2.72 \\
\hline
\end{tabular}


Original Article

\begin{tabular}{ccccccccc}
\hline L7 & 96.12 & 2.89 & 0.62 & 26.41 & 82.59 & 25.43 & 101.10 & 2.28 \\
L8 & 96.76 & 2.67 & 0.51 & 22.19 & 83.73 & 19.51 & 101.56 & 3.30 \\
L9 & 96.98 & 2.44 & 0.75 & 28.76 & 77.98 & 25.10 & 100.06 & 2.41 \\
L10 & 98.45 & 3.74 & 0.77 & 24.55 & 81.51 & 23.41 & 96.68 & 2.45 \\
L11 & 97.68 & 3.18 & 0.82 & 19.29 & 85.66 & 17.79 & 98.10 & 2.62 \\
L12 & 98.54 & 2.90 & 0.83 & 17.33 & 89.92 & 16.09 & 97.45 & 2.85 \\
L13 & 99.72 & 3.44 & 0.89 & 28.71 & 83.71 & 25.45 & 98.08 & 1.19 \\
L14 & 99.59 & 3.47 & 0.83 & 21.93 & 88.27 & 22.09 & 97.51 & 0.78 \\
L15 & 98.80 & 3.42 & 0.75 & 24.24 & 84.62 & 24.11 & 101.40 & 1.71 \\
L16 & 97.54 & 3.52 & 0.62 & 9.67 & 91.28 & 21.16 & 99.72 & 0.523 \\
\hline
\end{tabular}

\section{In-vitro dissolution study}

In this present study newer concept was applied to know effects of various categories of superdisintegrants on Lornoxicam fast dissolving tablets prepared by three approaches namely; superdisintegrant addition, sublimation, and solid dispersion techniques. The results obtained from the dissolution study are included in table 7. All sixteen formulae showed acceptable dissolution rate, where more than $85 \%$ to $90 \%$ of the labelled dose was dissolved at 30 minutes. The order of increased drug dissolution using three different techniques are as follows; solid dispersion>sublimation>superdisintegrant addition. In case of superdisintegrant addition technique; formulae L3 and L4 containing $2.5 \%$ and 5\% Gaur gum as super disintegrating agent showed increased dissolution rate after 15 min from 69.87 to $70.95 \%$ compared to formulae containing Crospovidone as super disintegrating agent, $58.23 \%$ and $61.11 \%$ for $\mathrm{L} 1$ and $\mathrm{L} 2$ respectively.

Combined approaches namely superdisintegrant addition with sublimation or solid dispersion resulted in an increased dissolution rate of the drug. The incorporation of 5\% Gaur gum in the formulae L12 prepared by sublimation method showed increased dissolution rate compared to tablet formulation prepared by superdisintegrant addition i.e. formulae L1 to L4. Formulae L12 containing camphor $10 \%$ showed the highest dissolution rate where $91.98 \%$ of labelled dose released at $10 \mathrm{~min}$; this might be due to increased surface porosity of tablets produced by sublimation of camphor which increased the penetration of dissolution medium into tablets thus accelerating the swelling of the Gaur gum and facilitating rapid tablet breakdown. Both formulation L4 and L12 contains same concentration and category of superdisintegrant but formulae L12 showed highest dissolution rate which might be due to presence of camphor. Formulae L13-L16 were prepared by another combined approach; superdisintegrant addition with Lornoxicam solid dispersions using PEG 6000 as polymeric carrier. Formulae L16 containing the drug and carrier ratio of 1:4 solid dispersion as well as Gaur gum 5\% showed increased dissolution rate of drug to $98.43 \%$ compared to that drug released from remaining formulations, this might be due to formulation containing solid dispersion exhibited higher degree of drug amorphization. 
Original Article

Table 7: Dissolution parameters of Lornoxicam fast dissolving tablets prepared by three different methods.

\begin{tabular}{|c|c|c|c|c|c|}
\hline \multirow{2}{*}{$\begin{array}{c}\text { Formulation } \\
\text { Code }\end{array}$} & \multicolumn{5}{|c|}{ Dissolution parameters } \\
\hline & $\mathbf{D}_{1 \min }$ & $\mathbf{D}_{5 \min }$ & $\mathbf{D}_{10 \mathrm{~min}}$ & $D_{15 \min }$ & $\mathbf{D}_{30 \min }$ \\
\hline L1 & 8.450 & 25.430 & 27.300 & 58.230 & 72.200 \\
\hline $\mathbf{L} 2$ & 9.700 & 28.450 & 50.450 & 61.110 & 74.110 \\
\hline $\mathbf{L 3}$ & 9.450 & 31.040 & 44.340 & 69.870 & 77.940 \\
\hline L4 & 13.290 & 37.120 & 58.240 & 70.950 & 80.090 \\
\hline L5 & 14.200 & 36.520 & 52.120 & 65.420 & 74.280 \\
\hline L6 & 17.010 & 38.400 & 58.540 & 72.200 & 85.900 \\
\hline L7 & 15.730 & 38.120 & 59.590 & 72.550 & 88.570 \\
\hline L8 & 22.260 & 43.220 & 48.210 & 81.650 & 94.740 \\
\hline L9 & 15.230 & 41.010 & 47.230 & 65.220 & 70.420 \\
\hline L10 & 18.500 & 46.120 & 52.030 & 69.410 & 81.100 \\
\hline L11 & 19.240 & 47.210 & 59.120 & 71.620 & 78.620 \\
\hline L12 & 25.440 & 49.030 & 61.240 & 75.330 & 93.450 \\
\hline L13 & 20.450 & 44.120 & 57.430 & 72.470 & 89.600 \\
\hline L14 & 24.090 & 51.060 & 62.790 & 86.430 & 96.210 \\
\hline L15 & 27.520 & 48.270 & 55.690 & 82.180 & 94.190 \\
\hline L16 & 22.3630 & 52.9330 & 65.810 & 89.330 & 98.430 \\
\hline
\end{tabular}


Original Article

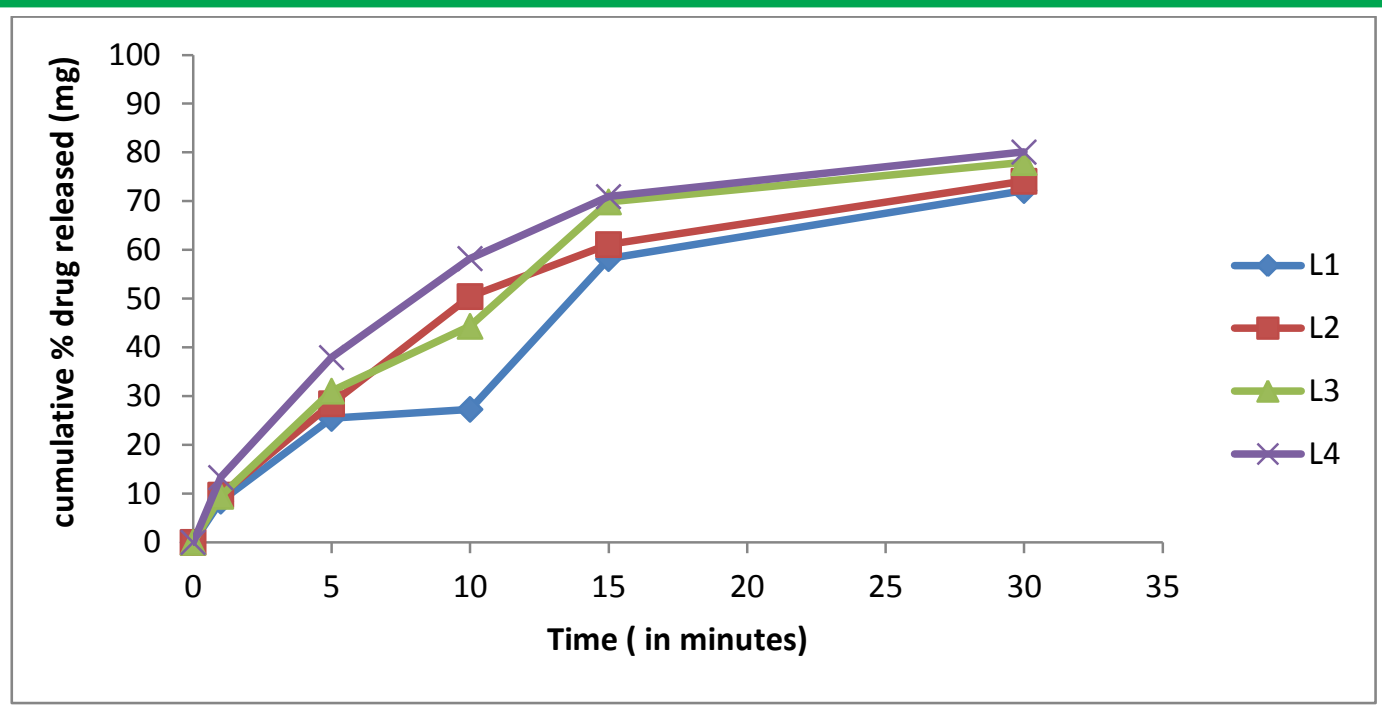

Fig 6: Dissolution profiles of Lornoxicam fast dissolvingtablets prepared by superdisintegrants addition method

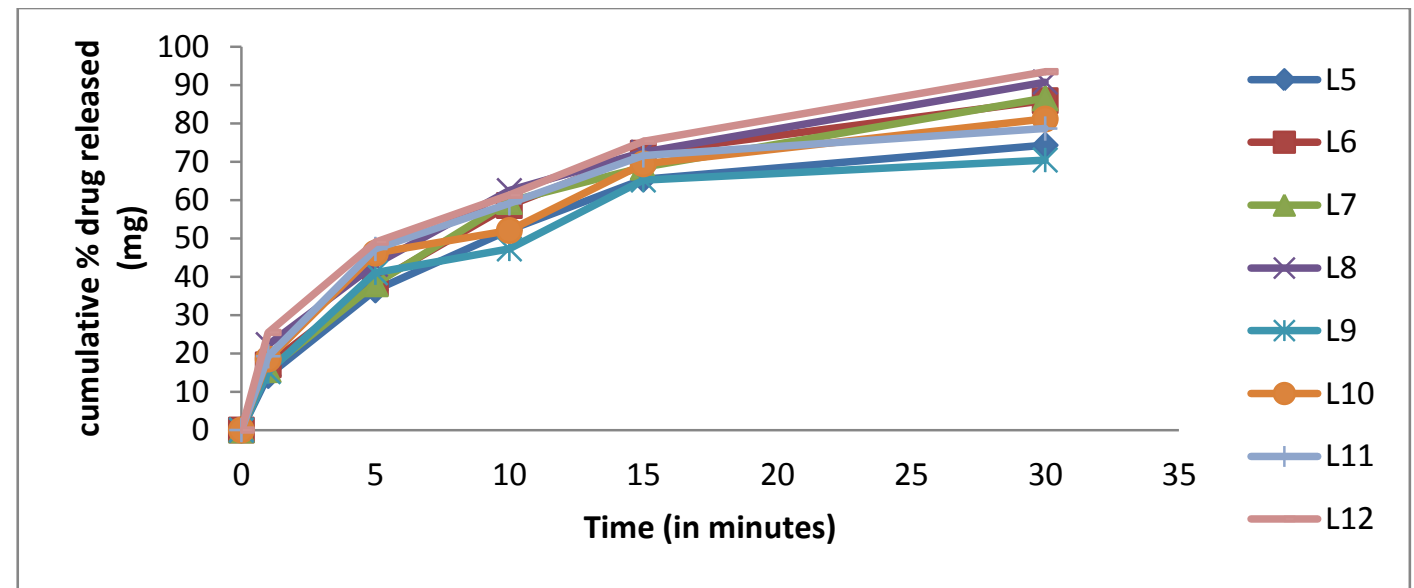

Fig 7: Dissolution profile of Lornoxicam fast dissolving by first combined approaches; sublimation + superdisintegrants addition method

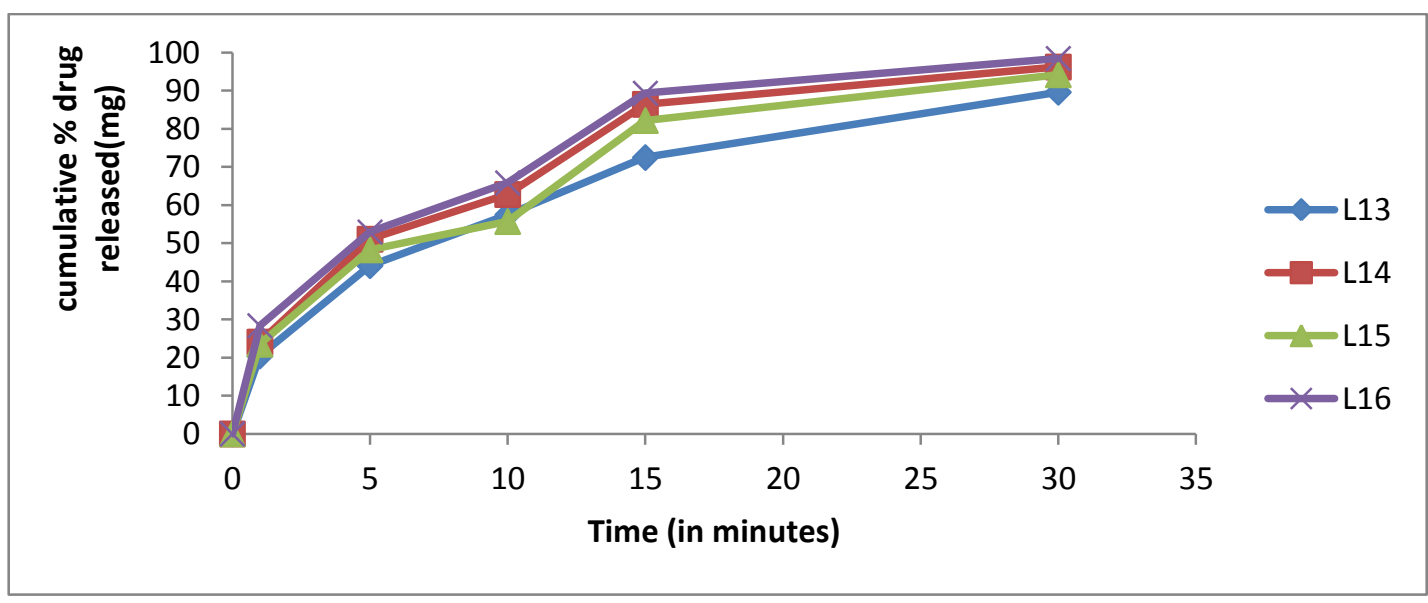

Fig 8: Dissolution rate profiles of Lornoxicam fast dissolving tablets prepared by second combined approaches; solid dispersion + superdisintegrants addition method 


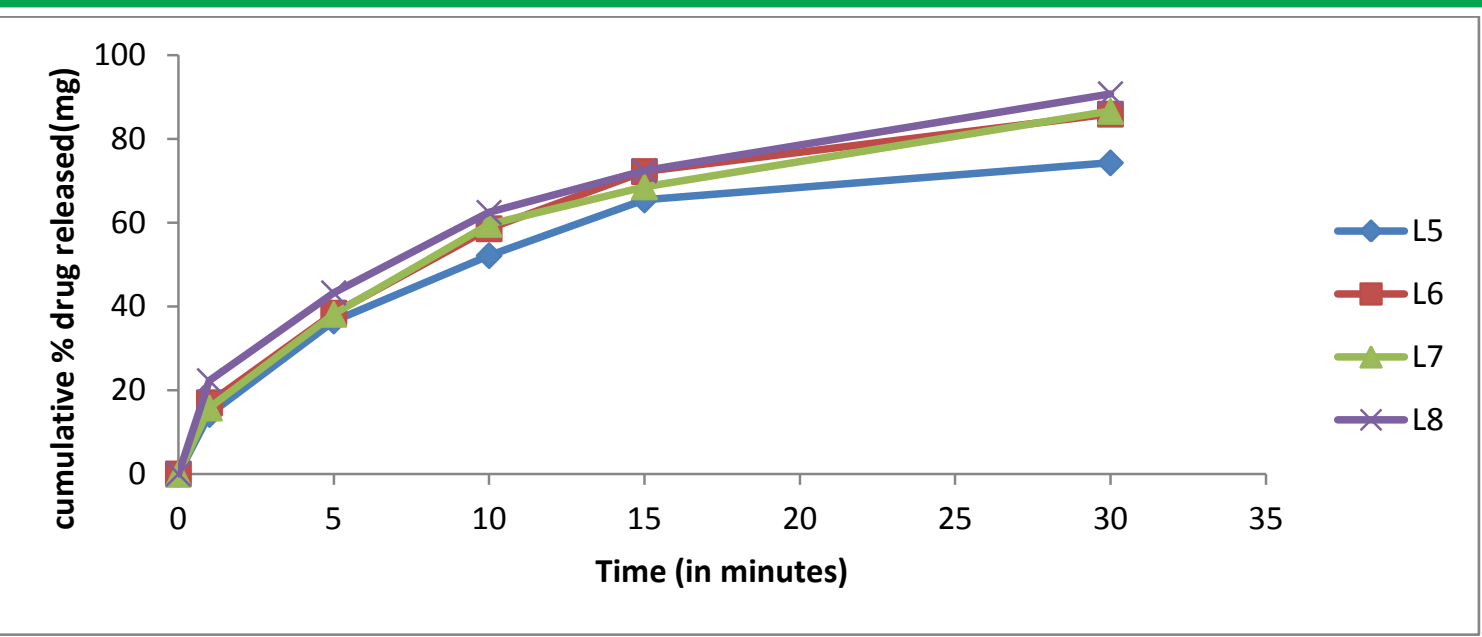

Fig 9: Effect of different concentrations of superdisintegrants [2.5\% (L5), and 5\% (L7)] and subliming agents (camphor) [5\% (L5), and 10\% (L8)] on dissolution rate profiles of Lornoxicam fast dissolving tablets

\section{Release kinetics studies}

Kinetic release studies were performed for formulae L16. Based on the " $n$ " value of 0.458 obtained for formulae L16, the drug release was found to follow Fickian (case I) release. Also, the drug release mechanism was best explained by first order release kinetics.It was found that the value of ' $r$ ' is 0.9885 , which is near to 1 when compared to Higuchi square root (0.960) and Zero order kinetic (0.782) model. The drug release kinetics of formulae L16 best fitted to first order release kinetics model. Results of release kinetics studies are shown in table 8 .

Table 8: In-vitro kinetic release studies of formulation L16

In-vitro release kinetic models

\begin{tabular}{lccccc}
\hline Formulae & Zero order & First order & Higuchi & \multicolumn{2}{c}{ Korsmeyer-Peppas } \\
\hline L16 & $\mathrm{R}^{2}$ & $\mathrm{R}^{2}$ & $\mathrm{R}^{2}$ & $\mathrm{R}^{2}$ & $\mathrm{~N}$ \\
& 0.789 & 0.9885 & 0.960 & 0.936 & 0.458 \\
\hline
\end{tabular}

\section{Stability Testing}

Based on the results obtained from disintegration time and dissolution of Lornoxicam from its fast dissolving tablets, formulae L16 was considered as best. So, formulae L16 was choosen for stability testing. Results obtained from stability testing showed no any changes in colour or apperance of prepared fast dissolving tablets throughout the storage period. There is no signifiant change in the dissolution rate profile of Lornoxicam from its fast dissolving tablets stored at $25^{\circ} \mathrm{C} / 60 \%$ and $45^{\circ} \mathrm{C} / 75 \%$ relative humidity but $1.23 \%$ of weight was increased after 3 month, which was under limits (as per ICH-Guidelines). 
Table IX: Results of stability studies

\begin{tabular}{|c|c|c|c|c|c|c|c|c|}
\hline \multirow{3}{*}{$\begin{array}{l}\text { Stability } \\
\text { period }\end{array}$} & \multicolumn{8}{|c|}{ Stability conditions } \\
\hline & \multicolumn{4}{|c|}{$25^{\circ} \mathrm{C} / 60 \% \mathrm{RH}$} & \multicolumn{4}{|c|}{$45^{\circ} \mathrm{C} / 75 \%$ RH } \\
\hline & Hardness & $\begin{array}{c}\% \\
\text { Friability }\end{array}$ & $\begin{array}{c}\text { Drug } \\
\text { content }\end{array}$ & $\begin{array}{c}\text { Dissolution } \\
\text { Profile }\end{array}$ & Hardness & $\begin{array}{c}\% \\
\text { friability }\end{array}$ & $\begin{array}{c}\text { Drug } \\
\text { content }\end{array}$ & $\begin{array}{c}\text { Dissolution } \\
\text { profile }\end{array}$ \\
\hline Initial & 3.52 & 0.62 & 99.72 & 98.43 & 3.52 & 0.62 & 99.72 & 98.43 \\
\hline $\begin{array}{c}\text { After } \\
1 \\
\text { month }\end{array}$ & 3.50 & 0.65 & 99.70 & 98.22 & 3.42 & 0.67 & 99.64 & 98.19 \\
\hline $\begin{array}{c}\text { After } \\
2 \\
\text { month }\end{array}$ & 3.38 & 0.72 & 99.68 & 98.04 & 3.21 & 0.77 & 99.39 & 97.54 \\
\hline $\begin{array}{c}\text { After } \\
3 \\
\text { month }\end{array}$ & 3.18 & 0.75 & 99.54 & 97.56 & 2.98 & 0.83 & 99.12 & 97.21 \\
\hline
\end{tabular}

\section{CONCLUSION}

Fast dissolving tablets of Lornoxicam could be considered as useful solid oral dosage form as it increases drug dissolution rate which is directly related to its bioavailability. Among three approaches, combined approaches of solid dispersion and super disintegrant addition technique could be applied more effectively in formulating fast dissolving tablets with better disintegration as well as drug release properties. Therefore solid dispersion of Lornoxicam: PEG 6000 in the ratio of 1:4 along with addition of Gaur gum as natural superdisintegrant was found to improve the dissolution properties of the tablets prepared by the combined approach.

\section{ACKNOWLEDGEMENTS}

The authors are thankful to Sri Adichunchanagiri College of Pharmacy, B.G Nagara for providing all necessary facilities.

\section{REFERENCES}

1. Monudeep BL, Kiran Kumar GB, Mohammed GA and Sudheer K. Design and in-vitro evaluation of taste masked fast dissolving tablets of Sumatriptan succinate. Int J Pharma Sci. 2013;4(4):305-14.

2. Shah R, Shah D, Patel CA and Keraliya RA. A comprehensive review on fast disintegrating tablets and its manufacturing techniques. Int J Mod Pharm Res. 2013; 2(2):24-65.

3. Jyothi RL, Abbulu K, Nagabushan RT and Akhila A. Formulation and evaluation of fast dissolving tablets of Lornoxicam. Int J Pharma. 2013; 3(3):579-86. 
4. Fu Y, Yang S, Jeong SH, Kimura S and Park K. Orally fast disintegrating tablets: developments, technologies, test masking and clinical studies. Crit Rev Ther Drug Carrier Sys. 2004; 21(7): 433-75.

5. Sastry SV, Nyshadham JR and Fix JA. Recent technological advances in oral drug delivery. A review. Pharm Sci Technol Today. 2000; 3(4):138-45.

6. Habib W, Khankari RK and Hontz J. Fast-dissolve drug delivery systems. Crit Rev Ther Drug Carrier Sys. 2000; 17:61-72.

7. Elkhodairy KA, Hassan MA and Afifi SA. Formulation and optimization of orodispersible tablets of Flutamide. Saudi Pharma J. 2014; 22: 53-61.

8. Rowe RC, Shestey PJ, Weller PJ. Hand book of pharmaceutical excipients. $4^{\text {th }}$ ed. London, Chicago. Pharmaceutical press, American Pharmaceutical Association. 2003; 519-521.

9. Senthil S, Bhama S, Ramya RR, Chandrasekhar Y and Perumal P. Orodispersible tablets of Lornoxicam with natural and synthetic super disintegrants. Int J Pharma Tech. 2011; 3(3): 3130-42.

10. Patil SC, Payghan SA, Disouza JI. Formulation and evaluation of oral disintegrating tablet of Lornoxicam. Int J Pharma Bio Arc.2011; 2(5): 1518-23.

11. Deshmukh KR and Jain SK. Development of Aceclofenac fast dissolving tablets using solid dispersion techniques: in-vitro evaluation. Ind J Pharma Edu Res. 2012; 46(2): $97-$ 104.

12. Upare SW, Chandewar AV, Kshirsagar MD, Koli US and Pokale HK. Formulation and development of orodispersible tablet of Lornoxicam. The Pharma Innovation. 2012; 1(6): 49-60.

13. Patil SC, Payghan SA and Disouza JI. Formulation and evaluation of oral disintegrating tablet of Lornoxicam. Int J Pharma Bio Arc.2011; 2(5): 1518-23.

14. Prasad Byrav D S, Medhi B, Prakash A, Patyar S and Wadhwa S. Lornoxicam: a Newer NSAID. IJPMR. 2009; 20 (1):27-31.

15. file:///D:/my\%20work/lor/DrugBank\%20\%20Lornoxicam\%20\%28DB06725\%29.htm

16. Gaur K, Tyagi LK, Kori ML, Sharma CS, Nema RK. Formulation and characterization of fast disintegrating tablets of Aceclofenac by using sublimation method. IJPSDR. 2011; 3(1): 19-22.

17. Rane DR, Gulve HN, Patil Vasant VV, Thakare VM and Patil VR. Formulation and evaluation of fast dissolving tablet of Albendazole. Int Cur Pharma J. 2012; 1(10):31116.

18. Sukhavasi $\mathrm{S}$ and Kishore VS. Formulation and evaluation of fast dissolving tablets of Amlodipine besylate by using Fenugreek seed mucilage and Ocimum basilicum gum. Int Cur Pharma J. 2012; 1(9): 243-49.

19. Elbary AA, Ali AA and Aboud HM. Enhanced dissolution of Meloxicam from orodispersible tablets prepared by different methods. Bulletin of Faculty of Pharmacy, Cairo University. 2012; 50: 89-97.

20. Basak SC, Selvin CDS and Sabapathy R. Formulation and in-vitro evaluation of Amoxicillin dispersible tablets. The Indian Pharmacist. 2006; 5(49): 71-03.

21. Mahesh E, Kiran Kumar GB, Mohammed GA and Kumar KP. Formulation and evaluation of Montelukast sodium fast dissolving tablets. Asian J Biomed Pharma Sci.2012;2(14):75-82. 
Original Article

22. Mohanty S, Mohan GK, Reddy MS. Formulation, evaluation and optimization of sustained release microcapsules of lornoxicam prepared with Gum dikamali and pectin extracted from Dillenia indica. Int J Chem Sci. 2015;13(1):97-106 